\title{
Energy Grass as Raw Material for MDF Production
}

\author{
Tibor L. ALPÁR ${ }^{a^{*}}-$ Gábor MARKÓ $^{b}$ \\ ${ }^{a}$ Institute of Wood-based Products and Technologies, Simonyi Károly Faculty of Engineering, \\ Wood Sciences and Applied Arts, University of Sopron, Sopron, Hungary \\ ${ }^{\mathrm{b}}$ Markó Co., Győr-Ménfőcsanak, Hungary
}

\begin{abstract}
Medium density fiberboards are widely produced and used in Europe. The main raw materials used in Hungary are beech (Fagus sylvatica), hornbeam (Carpinus betulus), poplar (Populus spp.) and pine (Pinus spp.). Governmental subsidizing of biomass for power plants has created economic pressure and a shortage of wood prompting a major producer of energy grass to initialize a project to examine the possibility for the production of MDF from energy grass "Szarvasi-1" (Elymus elongatus (Agropyron elongatum) cv. Szarvasi-1). Prior to this, no research results on the experimental production of MDF from energy grass had been published. In our research study, energy grass was defibrated and MDF boards were produced with the use of different adhesives. Standard tests were completed to evaluate the suitability of this alternate raw material in MDF production. The best result was achieved with phenol formaldehyde (PF) adhesive.
\end{abstract}

\section{energy grass / MDF / dry process / annual plant}

Kivonat - Energiafü alkalmazhatósága MDF gyártásában. A közepes sűrüségü farostlemezeket széles körben gyártják és használják Európában. A legfontosabb magyarországi nyersanyagok a bükk (Fagus sylvatica), a gyertyán (Carpinus betulus), a nyárak (Populus spp.) és a fenyőfélék (Pinus spp.). A biomassza energetikai célú felhasználásának kormányzati támogatása gazdasági nyomást és faanyaghiányt eredményezett, amely az energiafü fö termelöjét arra késztette, hogy egy projektet kezdeményezzen a "Szarvasi-1" (Elymus elongatus (Agropyron elongatum ) cv. Szarvasi-1) energiafü MDF gyártásában való alkalmazhatóságának bevizsgálására. Ezt megelőzően nem publikálták kutatási eredményeket az energiafü MDF célú kísérleti gyártásáról. Kutatásunk során az energiafüvet defibráltuk és MDF lemezeket készítettünk belőle különböző ragasztóanyagok felhasználásával. Szabványos vizsgálatokat végeztünk ezen alternatív nyersanyagok MDF gyártására való alkalmasságának értékelésére. A legjobb eredményt fenol-formaldehid (PF) ragasztóanyaggal értük el.

energiafü / MDF / száraz eljárás / egynyári növény

\section{INTRODUCTION}

Medium density fiberboard (MDF) is one of the most commonly used wood-based panels composed of wood fibers, bonded with adhesive, and cured under heat and pressure (Koch 1972; Maloney 1993; Saligna et al. 2001). In the decade before the 2008 economic crisis, the

\footnotetext{
*Corresponding author: alpar.tibor@uni-sopron.hu; H-9400 SOPRON, Bajcsy-Zs. u. 4, Hungary
} 
production of MDF had quadrupled in Europe and had a major market share in the wood composites industry. The total production capacity of MDF for the year 2005 was 1.350 .000 $\mathrm{m}^{3}$ (EPF 2006). Currently, 5\% of round wood of softwood and hardwood species, $75 \%$ recycled wood, and $20 \%$ mill residues are used as raw material to manufacture MDF (EPF 2006). MDF is used to manufacture molding, laminated flooring, packaging materials, containers, and overlaid panels for the furniture and cabinet industry. Compared to wood, fiberboard has a looser texture and lower internal strength; therefore, it does not require strong adhesives (Zhong et. al. 2002). Following the upturn in 2010, MDF production continued to grow slightly (up by $3.7 \%$ ) in 2011, reaching 14.1 million $^{3}$ in Europe (Eastin et al. 2012). From 2014 to 2015, MDF production showed a 2.7\% growth in Europe as EPF (2016) reports.

Low quality lignocellulosic materials from wood, sawdust, used furniture, agricultural wastes, different grass species, and other biomass products can be raw material for MDF production. The overall cost and environmental load can be reduced by the utilization of these waste raw materials. Several publications report research on different annual plants as possible raw materials for industrial utilization, e.g. rapeseed stalks, straw, and switch grass. This research focused on annual plant residues from agricultural production, especially from industrial plantations. This raw material became known under the term energy grass.

Pahkalaa et al. (2008) examined the possibilities of the energetic use of energy grass (reed canary grass) in Finnish power plants. In 2006, 2,300 ha of energy grass was grown for power plants in the Ostrobothnia region, Finland. Xu et al. (2011) reported on another use of energy grass through their results on the delignification of three types of switch grasses (Panicum virgatum) for bioethanol production in the USA. They described an effective prediction on the lignin reduction and sugar production of switchgrass. Kaur et al. (2010) examined two other grass types that they used as raw material for oil extraction. The researchers have done pulping experiments of the production residues on vegetable oil distillation. Both types of grasses yielded $41-43 \%$ pulp, which could be used for production of printing paper. Tofanica et al. (2011) examined rapeseed (Brassica napus) stalks, which is used as biofuel raw material in different forms. Stalks have higher extractives and soluble contents, which may cause lower pulping yields. Another fast growing species, Johnson grass, (Sorghum halepense) was tested by Albert et al. (2011), and examined for its suitability for paper production. They have concluded that Sorghum halepense fibers can be used for paper production only after being mixed with other longer fibers.

MDF is widely produced and used in Europe. In Hungary, the main raw materials are beech (Fagus sylvatica), hornbeam (Carpinus betulus), poplar (Populus spp.) and pine (Pinus spp.). In the past decade, governmental subsidizing of biomass electric power generation caused a shortage of wood raw material for the wood panel industry. In addition, farms started to produce annual plants for energetic use, but this was never introduced in power plants due to the ease of procuring and burning of wood. In these circumstances, a major producer of energy grass (Bóly Co.) started a project to examine the possibility of production of MDF from energy grass Szarvasi-1 (Elymus elongatus (Agropyron elongatum) cv. Szarvasi-1). The giant grass or so-called energy grass Szarvasi-1 was cross-fertilized for 10 years in Szarvas, Hungary as reported by Jankowsky et al. in 2004. Cross-fertilization of plant materials collected in the sodic soil areas of the Great Plain and in the arid areas of Central Asia was completed. Energy grass grows to a height of 2 meters. It has small spear-like seeds, and looks like huge couch grass (Jankowsky 2003). It was planted in larger agricultural areas after 2000. Possible uses as biomass fuel for power plants and as raw material for cellulose end paper production were examined with positive results. On one hectare, 10-15 t/a dry matter can be grown, which can produce 15 (GJ/ha) of energy. (Janowszky et al. 2012) Research by Lele et al. (2004) was conducted on Szarvasi-1 as a raw material for paper production. Since 
production costs are considerably lower than for existing pulp production processes, this presents a very attractive and economically viable commercial proposition, which can result in the establishment of a large scale pulp mill in Hungary. Szántó et al. (2003) successfully produced hard fiberboard with a wet process (HB) from the Szarvasi-1 energy grass on an industrial scale. This research produced boards with strengths similar to those produced by wood fibers, yet with lower density values and high thickness swelling.

No reports of grass used in this manner was found, especially none concerning energy grass for fiberboard production by dry process (MDF). Klie (2005) made $4 \mathrm{~mm}$ MDF boards by mixing energy grass fibers with wood fibers (from $0 \%$ to $100 \%$ giant grass content by $20 \%$ steps) and urea formaldehyde (UF) resin, but without the addition of paraffin. The results showed high thickness swelling (average 50\%), low internal bond (average $0.22 \mathrm{MPa}$ ) values, and low MOR (average $10 \mathrm{MPa}$ ) values. Klie's results showed that the preparation of energy grass for MDF production requires special technology. Giant grass alone, without being mixed with wood fibers, is not suitable for the production of MDF. The aim of the present study was to evaluate the mechanical properties of MDF boards produced from energy grass mixed with wood fibers when using alternate adhesives like phenol formaldehyde (PF) and melamine urea formaldehyde (MUF). Urea formaldehyde (UF) served as a control, to provide wood composite panel manufacturers with a comparison basis.

Markessini et al. (1997) produced experimental MDF boards (6 mm thickness, $700 \mathrm{~kg} / \mathrm{m}^{3}$ density) from wheat straw where a chemi-thermomechanical treatment was applied to produce fibers. They used pMDI (polimeric 4.4'-Methylene diphenyl isocyanate) and UF resins (15\% resin content) (Table 1).

Table 1. Board properties of MDF from wheat straw fibers with a thickness of $6 \mathrm{~mm}$ (Markessini et al. 1997)

\begin{tabular}{lcc}
\hline Property & PMDI & UF \\
\hline internal bond $[\mathrm{MPa}]$ & 0.83 & 0.5 \\
bending strength $[\mathrm{MPa}]$ & 18.7 & 13.1 \\
modulus of elasticity $[\mathrm{MPa}]$ & 2,676 & 1,974 \\
\hline
\end{tabular}

\section{MATERIALS AND METHODS}

\subsection{Raw materials}

Two kinds of fibers were used as raw material during the experiments: wood fibers produced by the Hungarian fiberboard company, MOFA Co., (recently Kronospan-MOFA Hungary Ltd.), and hammermilled energy grass obtained from the BOLY Agricultural Company. The wood fibers were used as received, and the energy grass was defibrated in our laboratory.

The industrial wood fibers were $25 \%$ saw mill cut offs from low-density hardwood species (mostly Populus spp.), 25\% pine fiber logs (Pinus spp.) and 50\% low-density hardwood species logs (mostly Populus spp.).

The pretreatment parameters to produce wood fibers on an industrial scale were 8.4 bar steam pressure, $177^{\circ} \mathrm{C}$ temperature, and 3 minutes defibration time in an Asplund Defibrator. The pretreatment parameters for energy grass in the laboratory were boiling in water at $100^{\circ} \mathrm{C}$ in a Lorentzen type rotating autoclave for $30 \mathrm{~min}$. The dry content of the suspension was $250 \mathrm{~g} / \mathrm{L}$. The pre-softened energy grass was then defibrated in a disc defibrator in a wet condition. The distance of the disks was set to $0.1 \mathrm{~mm}$. The disintegrated energy grass fibers were then milled in a Hollander type mill for 20 minutes. The treated, wet energy grass fibers 
were stored in a well-ventilated room for 10 days. The initial and final dry matter contents were $120 \%$ and $10.1 \%$ respectively. The dried, agglomerated fibers were then broken up in a Retsch type laboratory mill with an $8 \mathrm{~mm}$ sieve hole. At the same time, the longer fractions were shortened. The final moisture content, obtained by drying in a laboratory drier at $60{ }^{\circ} \mathrm{C}$, was around $4 \%$.

The type and dry content of adhesives used in laboratory board production are given in Table 2 .

Table 2. Adhesives used during laboratory board production

\begin{tabular}{lcc}
\hline Adhesive type & Dry matter content [\%] & Catalyst \\
\hline Urea formaldehyde (UF) & 65 & $\left(\mathrm{NH}_{4}\right)_{2} \mathrm{SO}_{4}$ \\
Phenol formaldehyde (PF) & 44.93 & - \\
Melamine urea formaldehyde (MUF) & 65.6 & $\left(\mathrm{NH}_{4}\right)_{2} \mathrm{SO}_{4}$ \\
\hline
\end{tabular}

A $1.5 \%$ paraffin dispersion (calculated on dry matter content of fibers) was added to the fiber furnish in order to decrease water absorption. As a catalyst for the aminoplast adhesive (calculated on dry matter content of UF and MUF adhesives), 2\% ammonium sulfate, which cures in an acidic condition, was used. The concentration solution of ammonium sulfate was $35 \%$.

Fiber size distribution was determined by a Fritsch Analysette vibrating separator. The sieve hole diameters were in millimeters as follows for both raw materials: $0.08,0.18,0.315$, 1.0 , and 4.0 respectively.

The testing parameters were $5 \mathrm{~min}$. for duration of separation, $1.7 \mathrm{~mm}$ vibrating amplitude, $2.5 \mathrm{~mm}$ vibration amplitude, and a 5 second interval between two vibration impulses.

The degree of beating was tested by a Schopper-Riegler freeness tester and was measured in both raw materials: wood and energy grass fibers.

\subsection{Moisture content of fibers}

The moisture content of the mat plays an important role during hot pressing, so the moisture content of the mixture of fibers, adhesive and other additives has to be set carefully. The moisture in the mat helps to transport the heat from the hot plates into the core layer. If the mat is too dry, the time for total warm up will be too long causing the surface layers to dry out or be burned; in addition, the adhesive in the core layer will not get cured. If the moisture content of the mat is too high, the evaporating water cannot escape from the board under high pressure; this may cause the board to explode or delaminate when the press is opened. (Heller 1995).

The final moisture content of giant grass was $1.1 \%$ and that of the wood fibers was $1.0 \%$. The moisture content was determined based on standard EN 322.

\subsection{Experimental board production}

The following fiber mixtures were applied to produce boards in laboratory conditions: $0 \%$, $20 \%, 40 \%, 60 \%, 80 \%, 100 \%$ of energy grass fiber and the complementary amounts were wood fibers. Dry process fiberboards with dimensions of $500 \mathrm{~mm}$ square x $4 \mathrm{~mm}$ for UF and $300 \mathrm{~mm}$ square $\mathrm{x} 4 \mathrm{~mm}$ for PF and MUF were made from the wood and energy grass fibers. The samples with the specific gravities of 700 and $800 \mathrm{~kg} / \mathrm{m}^{3}$ were weighed and placed into a drum blend. While being tumbled in the rotating drum blend, the chemicals were sprayed with the appropriate amount of adhesives (Table 3). The paraffin emulsion was spread separately. 
A pre-calculated amount of blended raw materials was then hand-felted into a forming box and pre-pressed into a mat by $784 \mathrm{~N}(80 \mathrm{~kg})$. The mat was then hot-pressed with a SIEMPELKAMP laboratory heat press at different press conditions into $4 \mathrm{~mm}$ thickness guided by two rectangular steel stops. Press temperatures were $180^{\circ} \mathrm{C}$ and the pressure varied according to three pressing stages: $2.5 \mathrm{MPa}, 1.9 \mathrm{MPa}$, and $0.95 \mathrm{MPa}$. The hot-pressing time for each pressure stage was 64 seconds. After hot pressing, the pressure was gradually released; the boards were stored at room temperature and finally trimmed to remove the rough edges.

Table 3. Detailes of the three experimental runs

\begin{tabular}{lccc}
\hline Board parameters & UF-MDF & PF-MDF & MUF-MDF \\
\hline length of the board [mm] & 500.0 & 300.0 & 300.0 \\
width of the board [mm] & 500.0 & 300.0 & 300.0 \\
thickness of the board [mm] & 4.0 & 4.0 & 4.0 \\
desired oven dry density [kg/m $\left.{ }^{3}\right]$ & 650.0 & 700.0 & 700.0 \\
fiber : adhesive ratio & $0.88: 0.12$ & $0.92: 0.08$ & $0.90: 0.10$ \\
catalyst [\%] & 2.0 & - & 2.0 \\
paraffin dispersion [\%] & 1.5 & 1.5 & 1.5 \\
moisture content of mat [\%] & 8 & 8 & 8 \\
\hline
\end{tabular}

The ratio of adhesive was different according to Deppe - Ernst (1996) who recommend different ratios for different adhesive types to achieve similar board properties.

After 24 hours of conditioning, the boards were cut and tested according to the MSZ EN 310, 317, 319 and 323 standards. Modulus of elasticity (MOE), modulus of rupture (MOR), specific gravity (SG), and thickness swelling (TS) of the boards were determined. Static bending tests were done on an Instron 5566 universal testing machine to calculate MOE and MOR. The standard specimens were soaked in tap water for 24 hours to test thickness swelling. Requirements of EN 622-5 standard for MDF with thickness of $4 \mathrm{~mm}$ are listed in Table 4.

Table 4. Requirements for MDF with a thickness of $4 \mathrm{~mm}$

\begin{tabular}{lc}
\hline Property & Requirement (EN 622-5) \\
\hline thickness swelling - 24 h [\%] & $\operatorname{max.~35}$ \\
internal bond [MPa] & $\min .0 .65$ \\
bending strength [MPa] & $\min .23$ \\
modulus of elasticity [MPa] & - \\
\hline
\end{tabular}

\section{RESULTS AND DISCUSSION}

\subsection{Fiber size}

Figure 1 represents the mean values of fiber distribution. There are differences between the wood fibers and energy grass fibers; hence, the former was made on an industrial scale and the latter in laboratory conditions with different equipment. Important characteristics of fibers 
are the ratio of length and diameter (aka slenderness) and the surface structure, because they have a great influence on mat forming and on joining (felting) of fibers (Winkler 1999):

- for a wet production process, the long, slender, wavy fibers are the most suitable $1 / \mathrm{d}: 89-115$

- for a dry process, shorter, smoother, thin fibers are best $-1 / \mathrm{d}: 30-50$.

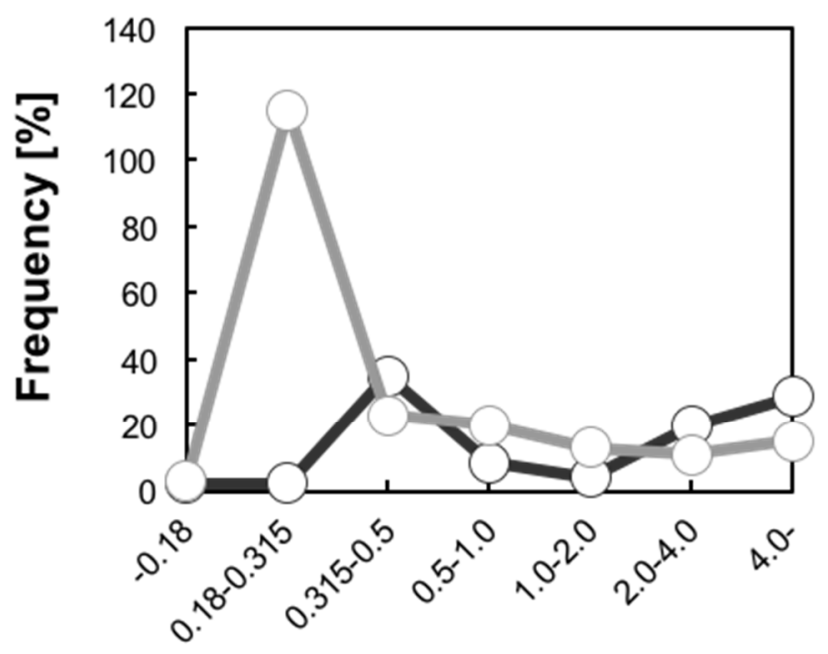

\section{Diameter of sieve holes [mm]}

$-\infty$ wood fibers $-\mathrm{O}=$ energy grass fibers

\section{Figure 1. Size distribution of the fibers}

The ratio of fine parts, (dust) is much higher in energy grass fibers from laboratory production. The reasons for this are: firstly, the annual plants contain more silica (2-4\%) and ash (4-8\%) than wood (close to 0\%) (Halvarsson et al. 2004), and secondly, the applied laboratory technique regarding the refining of the fibers in a Hollandi mill caused much shortening. For board production, the dust was eliminated from energy grass fiber raw material.

\subsection{Degree of beating of fibers}

The degree of beating of the two fibers were:

- wood: $10.3 \mathrm{SR}^{\circ}$

- energy grass: $8.7 \mathrm{SR}^{\circ}$

This means that wood component contains more fine fibers, and energy grass contains less fibrous particles, but energy grass has coarser elements and dust, as shown in Figure 1. This is caused by the laboratory techniques that were used.

\subsection{Experimental board properties}

Table 5. shows results of our recent research on boards made of 100\% energy grass fiber. 
Table 5. Board properties of MDF from 100\% energy grass

\begin{tabular}{llccc}
\hline Property & & UF & PF & MUF \\
\hline internal bond [MPa] & Mean & 0.26 & 0.10 & 0.42 \\
& Std. dev. & 0.0321 & 0.0219 & 0.0469 \\
bending strength [MPa] & Mean & 11.0 & 17.7 & 16.1 \\
& Std. dev. & 3.261 & 5.3597 & 2.4287 \\
& Mean & 1015 & 2022 & 1812 \\
modulus of elasticity [MPa] & Std. dev. & 124.0325 & 567.2913 & 218.0057 \\
& Mean & 63.08 & 45.37 & 38.32 \\
thickness swelling (24h) [\%] & Std. dev. & 4.5261 & 4.1724 & 4.6135 \\
\hline
\end{tabular}

Similar to Markessini et al.'s (1997) results (see above and Table 1), the strength values of boards with UF adhesive are the weakest, but strength of boards made with PF and MUF are close to the similar values of boards made with PMDI. In our case, no chemical treatment was applied, so the wax content of the fibers decreased the strength of the boards, especially regarding internal bond. Also in our case, only $12 \%$ of UF was used instead of $15 \%$, because dry blending was applied.

During this research grass fibers were mixed with wood fibers, where the ratio of energy grass was $0 \%, 20 \%, 40 \%, 60 \%, 80 \%$ and $100 \%$.

Mean values of results are shown in Figures 2-5.

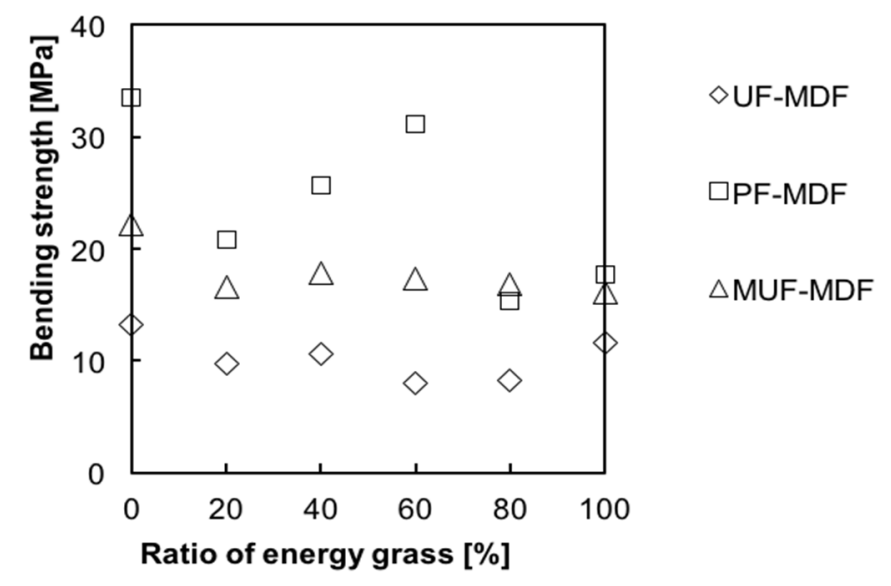

Figure 2. Comparison of bending strength mean values

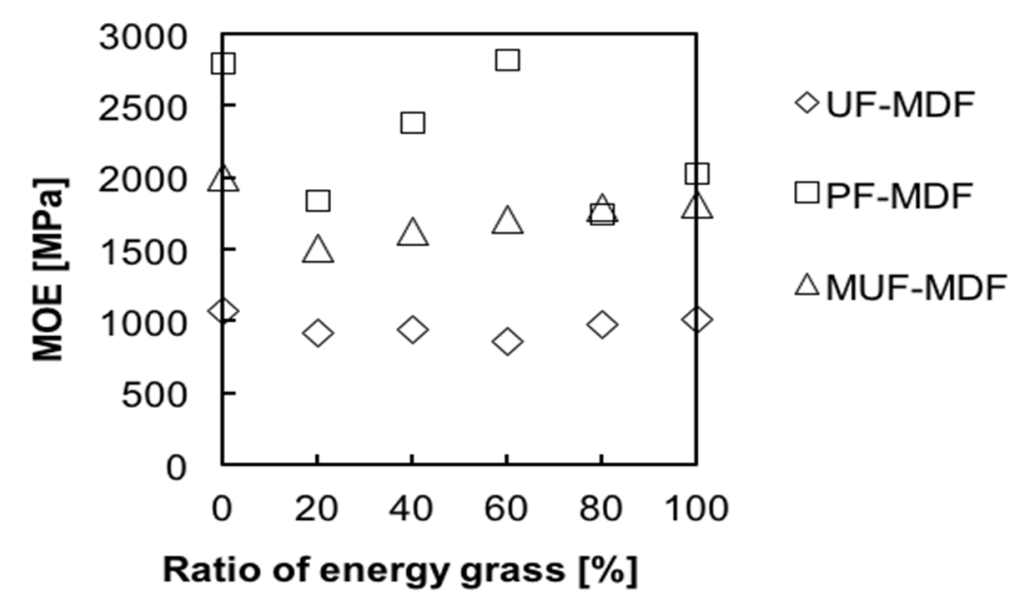

Figure 3. Comparison of modulus of elasticity mean values 
By comparing bending strength values (Figure 2) of the three experimental runs (UF, PF, MUF) it is clearly shown that UF type boards have the lowest values. Although the highest values come from using a PF adhesive, the MUF adhesive produced the most balanced results, so MUF is the least sensitive to the properties of giant grass fibers. Some abnormal values (those outside of the trend) are caused by uneven laboratory blending and manual mat forming. Halvarsson et al. (2004) reported successful laboratory experiments on wheat straw produced MDF with the addition of $15 \%$ and $19 \%$ melamine urea formaldehyde resin. Their results with urea formaldehyde resin were also unsatisfactory.

The trends of modulus of elasticity values (Figure 3) are very similar to the trends of bending strength values. Since these have no standard requirements, they are only for comparison among themselves. The values are the lowest in UF type boards, highest in PF type boards and most balanced in MUF type boards.

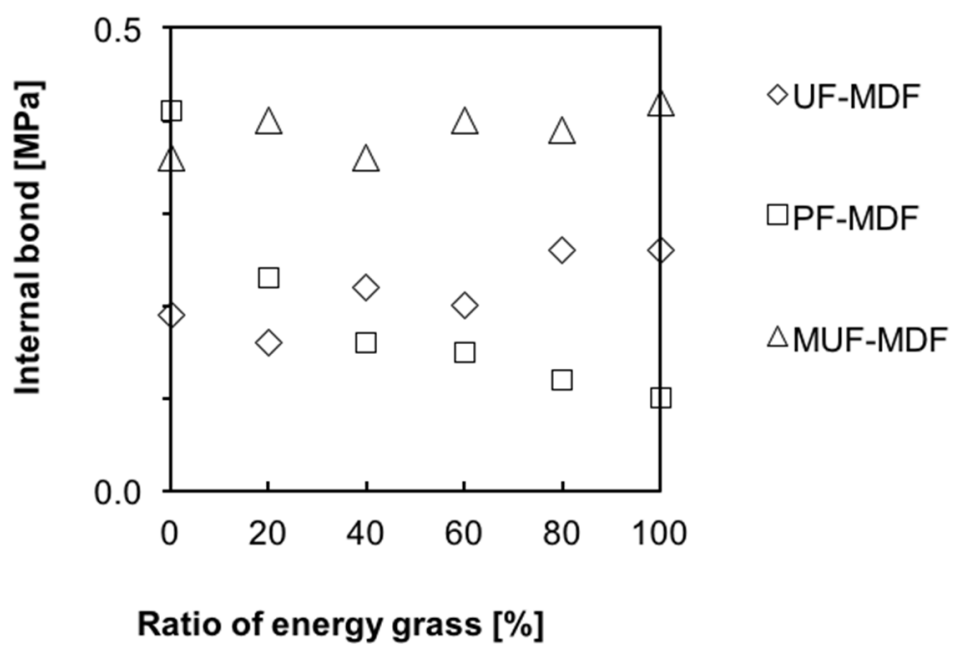

Figure 4. Comparison of internal bond mean values

Internal bond values (Figure 4) are below expectations. Hence, these were below standard requirements in every case, including the UF board produced by Markessini et al. (1997). The best results were found using MUF adhesive where the values were very balanced independent from the wood-grass ratio. The values of PF were very low, which shows that there is some incompatibility between the adhesive and grass. This is caused by the high wax content of the grass.

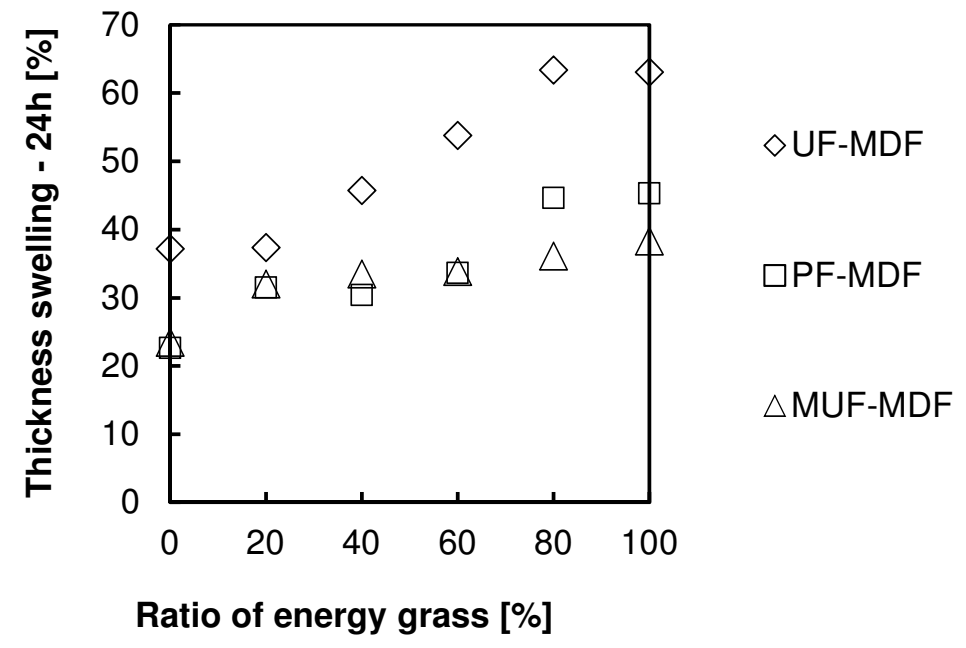

Figure 5. Comparison of thickness swelling mean values 
Thickness swelling (Figure 5) tests are usually not reported in publications because the standard requirements (max. 35\%) are difficult to fulfill. There were very clear trends in this research. None of the experimental boards using UF adhesive fulfilled the requirement. Using PF and MUF with up to $60 \%$ grass content, the thickness swelling values remained under $35 \%$. Again, the most balanced values were found with MUF. An increasing trend was found with every adhesive type when the ratio of energy grass was increased.

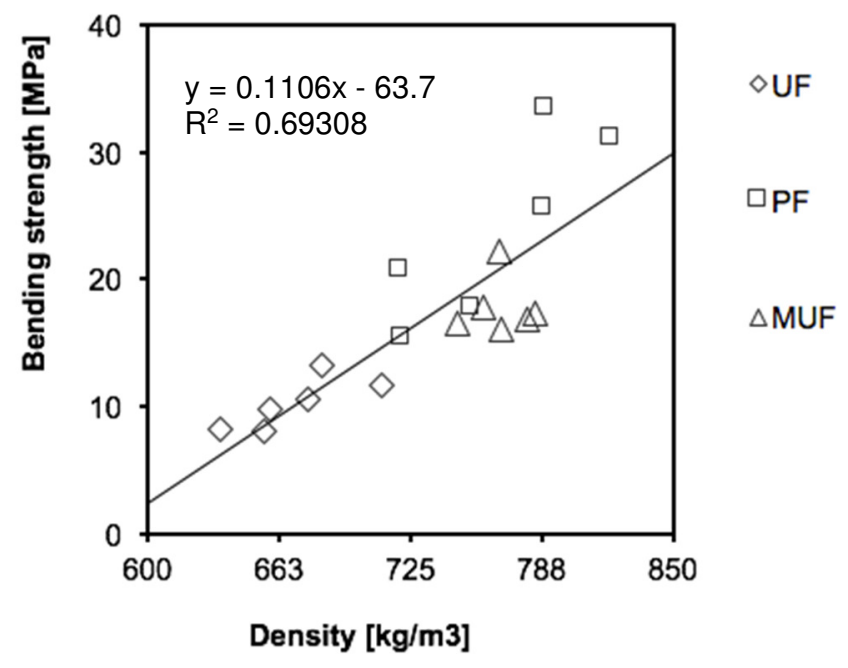

Figure 6. Bending strength as a function of density for all experimental boards

The bending strengths of the boards as a function of density are shown in Figure 6. Globally, a linear trend can be observed on the graph with increasing density, as is usually observable in the case of wood-based panels. This trend verifies that the measurements were correct. This increase in bending strength was found in all three types. Results are more balanced only in MUF type boards. In Fig.6, the bending strength depends only on density of the MDF. It does not depend on the ratio of the energy grass to wood fiber or on the type of adhesives. From these results it could be concluded that there is no difference between wood fiber and energy grass on the contributions for MDF properties except thickness swelling. In other words, energy grass can be used for MDF raw materials almost as effectively as wood fiber. However, the thickness swelling increased with the ratio of energy grass on any type of adhesives, so water absorption of energy grass may be a little bit higher than wood fiber.

On this graph, the disadvantage of manual mat forming is proven, as there is a large deviation in density across the surface of the board. The bending strength values show much lower values in the case of low-density test pieces.

The density of UF board types is lower than that of the others and this is partly the reason for their low strength values.

\section{CONCLUSIONS}

In this research, the possibility of producing MDF from energy grass using different adhesives was examined. The following can be concluded about the results of bending strength as a function of density:

- MDF boards made with UF adhesive are the weakest and had the lowest density values.

- Boards made with an MUF adhesive the most balanced strength values (MOR, MOE and IB). 
- The highest strength values (MOR, MOE and IB) were found in boards made with PF adhesive, but the deviations are also the largest here. It should also be noted that the lower strength values occurred with lower density, and it is well known that with such panel boards there is a linear correlation between density and bending strength as measured by Alpar (2007) and Deppe - Ernst (1996). These irregular values might be caused by manual mat forming.

Based on these results, the advantages of both MUF and PF adhesives are demonstrated. A co-condensed MUPF type adhesive could combine the good effect of both adhesives on the board properties. Our previous research results proved that mixing different types of adhesives like MUF and PF does not combine the advantages of these two adhesives. It should be a directly synthesized, co-condensed adhesive to gain the best strength (Winkler et al. 2007).

Energy grass can be grown at high yield; based on our results, it can be a potential raw material for MDF production.

Acknowledgments: Research was supported by Bóly Zrt and in frame of the „EFOP-3.6.116-2016-00018 - Improving the role of research+development+innovation in higher education through institutional developments assisting intelligent specialization in Sopron and Szombathely."

\section{REFERENCES}

Albert, S. - PAdhiar, A. - GANDHI, D. (2011): Fiber Properties of Sorghum halepense and Its Suitability for Paper Production. Journal of Natural Fibers 8 (4): 263-271.

AlPÁR, T. (2007): Farostlemez- és forgácslapgyártás gyakorlatok [Practice in fiberboard and partilcleboard production], University of West Hungary, Sopron, 91 p. (in Hungarian)

DEPPE, H-J. - ERNST, K. (1996): MDF - Mitteldichte Faserplatten [Medium density fiberboards], DRW Verlag, Leinfelden-Echterdingen. (in German)

EASTIN, I. - BROSE, I. - NovoselOV, I. (2012): Wood-based panel markets, 2011-2012 UNECE/FAO Forest Products Annual Market Review, 2011-2012.

European PANel Federation (2006): European Panel Federation Annual Report 2005-2006, EPF, Brussels: 299.

EUROPEAN PANEL FEDERATION (2016): EPF Market report. http://europanels.org/factsfigures/market-information (01.05.2017)

HALVARSSON, S. - NORGREN, M. - EDLUND, H. (2004): Manufacturing of fiber composite medium density fiberboards (MDF) based on annual plant fiber and urea formaldehyde resin, Proceedings of International Conference on Environmentally-Compatible Forest Products. Oporto, Portugal: 131-137.

Heller, W. (1995): Die Spanplatten-Fibel [The particleboard story], Author's edition, Hameln. 249259 (in German)

HURTER, R.W. (2001): Nonwood plant fiber characteristics. Extracted from "Agricultural Residues", TAPPI 1997 Nonwood Fibers Short Course Notes, updated and expanded August 2001.: 3-4.

JANKOWSZKY, J. - JANKOWSZKY Zs. (2004): Energy grass, (http://www.energiafu.hu/nemesit_en.html) (09.22.2016.)

JANKOWSZKY, Zs. (2003): Füfélék ipari célú hasznosítása [Industrial use of grass species], Acta agraria. 2003/10 (in Hungarian): 1-3.

JANOWSZKY, Z. - JANOWSZKY, J. - LELE, I. - LELE, M. - NAGY, H.J. - RUSZNÁK, I. - VÍG, A. (2012): New annual Hungarian plants (industrial grasses) as raw materials in the pulp and paper industry. Papíripar LVI (4): 3-7.

KAUR, H. - DUTT, D. - TYAGI, C. H. (2010): Optimization of soda pulping process of ligno-cellulosic residues of lemon and sofia grasses produced after steam distillation. BioResources 6 (1): 103-120. 
KLIE, Zs. (2005): MDF gyártása farostból és óriásfü felhasználásával [MDF production from wood fibers and giant grass], University of West Hungary, Sopron 32-35, 38 (in Hungarian)

Koch, P. (1972): Utilization of Hardwoods growing on southern Pine Sites, United States Department of Agriculture, Forest Service, Agriculture Handbook, No. 605.

LELE, I. (2004): Golden fields: utilization of Szarvasi-1 energy grass in paper industry, EU research project 'Objective 1' project report (http://ec.europa.eu/regional_policy/en/projects/hungary/fields-of-gold-utilization-of-szarvasi-1industrial-grass-in-the-paper-industry) 09.22.2016.

MALONEY, T. (1993): Modern Particleboard and Dry-Process Fiberboard Manufacturing, Miller Freeman Publishing Inc., San Francisco, CA.

MARKESSINI, E. - ROFFAEL E. - Rigal L. (1997): Panels from annual plant fibers bonded with ureaformaldehyde resins, $31^{\text {st }}$ International Particleboard/Composite Materials Symposium, Pullmann, USA.: 151,157

PAhKalaA, K. - Aaltob, M. - Isolahtic, M. - Poikolad, M. - Jauhiainen, L. (2008): Large-scale energy grass farming for power plants - A case study from Ostrobothnia, Finland. Biomass and bioenergy 32: 1009-1015.

SAlignA, A. - KizysiK, M. - Muehl, J.H. - YoungQuist, A.J. - Franco, F.S. (2001): Medium density fiberboard made from eucalyptus saligna, Forest Products Journal 51: 10.

SZÁNTÓ, D. - WINKLER, A. - NAGY J. (2003): Farostlemezek óriásfüből [Fiberboards (HB) from giant grass], Faipar 51 (3) 18-20 (in Hungarian)

Tofanica, B.M. - CAPPelletto, E. - Gavrilescu, D. - Mueller, K. (2011): Properties of Rapeseed (Brassica napus) Stalks Fibers. Journal of Natural Fibers 8(4): 241-262.

WINKLER, A. - ALPÁR, T. (2007): A hazai faanyagforrás jelentős bővítése, faültetvények létesítése és hasznosítása. 2.5. Új fafeldolgozási technológiák tudományos megalapozása üzemi kísérletekkel [Significant expansion of domestic wood sources, establishing and utilization of wood plantations. 2.5. Scientific background of new wood processing technologies in semi-industrial scale] Annual report for research project: NKFP4-0011/2005. Sopron (in Hungarian).

WINKLER, A. (1999): Farostlemezek [Fiberboards], Dinasztia Kiadó, Budapest 46. (in Hungarian)

XU, J. - Chen, Y. - Cheng, J.J. - SHARMA-ShivAPPA, R.R. - BuRnS, J.C. (2011): Delignification of switchgrass cultivars for bioethanol production. BioResources 6 (1): 707-720.

ZhONG, Z. - Sun, X.S. - FANG, X. - RATTO, Jo.A. (2002): Adhesive strength of guanidine hydrochloride - modified soy protein for fiberboard application, International Journal of Adhesion and Adhesives 22: 267. 
